\title{
EGLÊ MALHEIROS, SALIM MIGUEL E O INTERCÂMBIO ENTRE AS DUAS MARGENS DO ATLÂNTICO
}

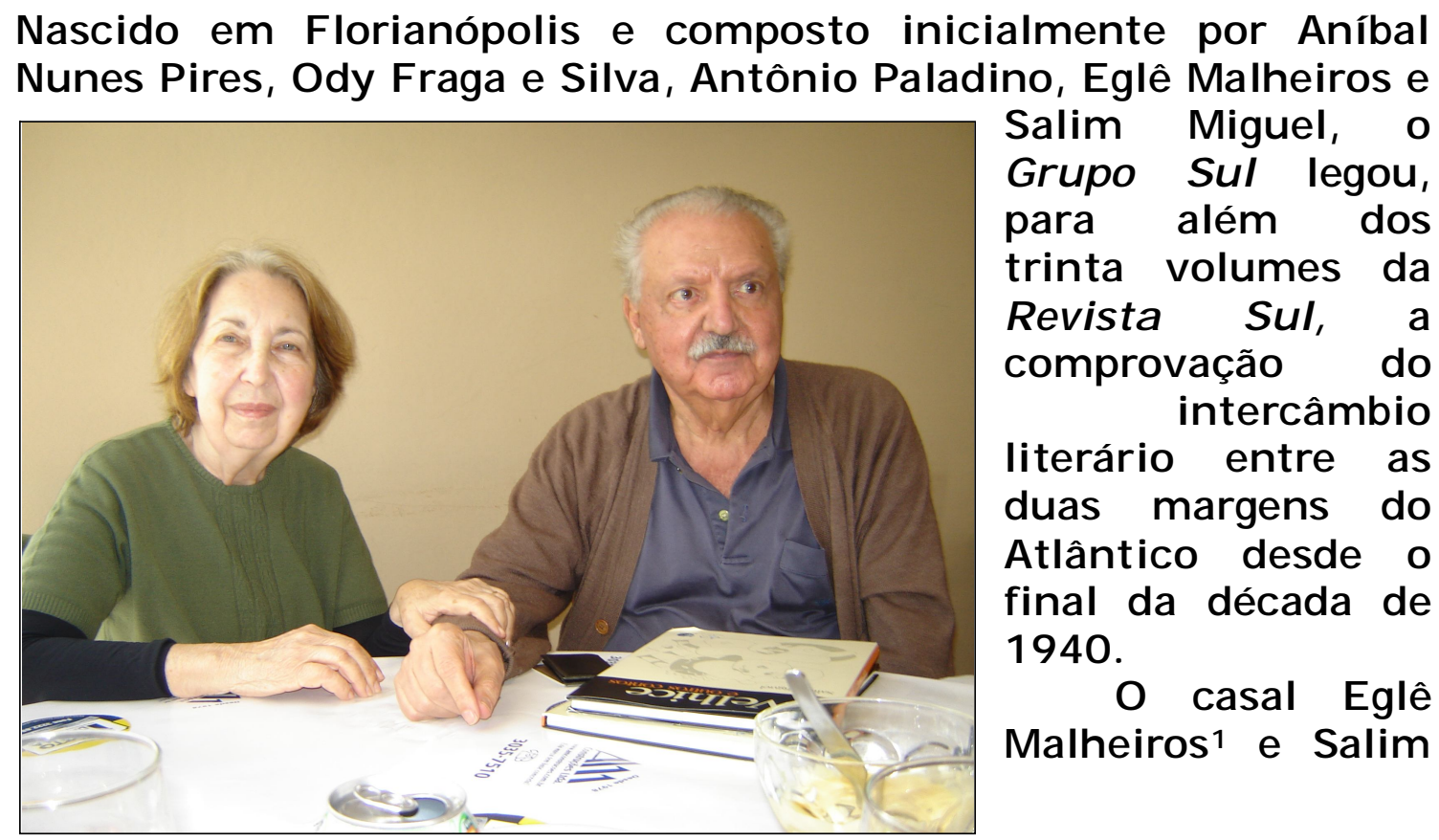

\footnotetext{
${ }^{1}$ Eglê Malheiros é natural de Tubarão, Santa Catarina. Bacharel em Direito pela UFSC e mestre em Comunicação pela UFRJ. Professora, escritora, tradutora, especialista em literatura infanto-juvenil. Foi uma das fundadoras do Círculo de Arte Moderna, conhecido como Grupo Sul (revista, editora, teatro, música, artes plásticas, clube de cinema, cinema), movimento que durante uma década (1948/1958) sacudiu o ambiente cultural de Santa Catarina, renovando-o e arejando-o. Com Salim Miguel, escreveu o argumento e roteiro de $O$ preço da ilusão, primeiro longa-metragem realizado em Santa Catarina. Em 1964, durante o golpe militar, foi presa e afastada da cátedra de História. A família teve que se mudar para o Rio de Janeiro. Lá trabalhou como tradutora, roteirista de cinema e na Fundação Nacional do Livro Infantil e Juvenil, do qual foi diretora-secretária. Foi, também, uma das editoras da revista Ficção (1976/79). Ministrou cursos, participou de comissões julgadoras no campo da ficção, colaborou como crítica literária na imprensa. Tem trabalhos de poesia, de ficção, de crítica, em órgãos de imprensa e livros. Em 1979, voltou para Florianópolis. Retomou, por curto período, até se aposentar, a cadeira de História do Instituto Estadual de Educação. Tem trabalhos inéditos e esparsos em órgãos de imprensa, que começa a organizar para publicação. (Dados extraídos da orelha de sua obra Vozes veladas; Porto Alegre: Movimento, 1995).
} 
Miguel $^{2}$ gentilmente abre a porta de sua casa para receber a Revista Crioula e fala sobre as realizações daquele grupo de jovens que se reunia em bares ou à sombra da grande figueira da praça e que movimentou culturalmente a então pacata cidade de Florianópolis, com destaque para a troca de correspondência e a publicação de textos de autores africanos de lingua portuguesa na Revista Sul.

\author{
Por Érica Antunes ${ }^{i}$ e Simone Caputo Gomes ${ }^{i i}$
}

Revista Crioula: Como começou o Grupo Sul, como surgiu a idéia de formá$10 ?$

Salim Miguel: Naquela época - não sei se hoje ainda acontece isso porque mudou tanto o relacionamento entre as pessoas - nós vivíamos numa "ilha ilhada”, onde a Semana de Arte Moderna, que já estava sendo reavaliada no Brasil, nem havia chegado ainda a Florianópolis. Nós tínhamos uma inquietação intelectual muito grande, nos reuníamos em bares e cafés menos a Eglê, que naquela época mulher não freqüentava tais lugares. E começamos então a furar os jornais da terra, mas isso era insuficiente. Aí, de repente, pensamos: "Por que não fazer uma revista?” Não queríamos só

\footnotetext{
${ }^{2}$ Com trinta livros publicados a partir de 1952, data da edição da antologia Velhice e outros contos, Salim Miguel é considerado, depois de Cruz e Sousa, o mais importante escritor de Santa Catarina. Muitos dizem que é a principal personalidade cultural catarinense do século XX. Nascido no Líbano em 1924, filho de um professor primário, Salim chegou ao Brasil três anos depois e, com a família, passou a viver em Biguaçu, pequena cidade próxima de Florianópolis. Editando o primeiro livro aos 28 anos, o escritor passa a liderar na década de 50 o movimento artístico de renovação das artes estaduais, conhecido por Grupo Sul, que, além de montagens de peças de teatro, edições de livros e exposições de artes plásticas, rodou o primeiro filme longa metragem de Santa Catarina, intitulado Preço da ilusão. Mudando-se para o Rio de Janeiro, Salim Miguel foi editor da revista de contos Ficção, uma das publicações literárias mais regulares e influentes do país. Já o seu livro mais conhecido e também mais premiado, é o romance Nur na escuridão, publicado em 1999, quando foi considerado pela crítica como o "livro do ano". Esta obra conta a aventura da emigração de uma família libanesa para o Brasil, trabalho que naturalmente se reveste de numerosos traços autobiográficos. Salim Miguel escreveu ainda os romances Mare nostrum e Voz submersa, a antologia de contos $O$ sabor da fome, e numerosos textos de crítica literária, de reminiscências de escritores e crônicas, como são os escritos desta antologia. Em 2002, o romancista foi apontado pela União Brasileira de Escritores como o "Escritor do Ano". Aos 84 anos, e em plena atividade, o grande autor catarinense deverá encerrar 2008 com a publicação de mais dois livros de ficção, completando 33 obras. Salim vive em Florianópolis. (Dados extraídos da orelha de sua obra Minhas memórias de escritores; Palhoça: Ed. Unisul, 2008).
} 
uma revista, tínhamos um projeto cultural: trabalhamos com teatro, cinema, artes plásticas, música...

Eglê Malheiros: Nunca tivemos estatutos nem registros.

Salim Miguel: É, a revista nunca foi registrada, tanto que de repente apareceu uma outra revista em Blumenau chamada Revista do Sul ou algo parecido, era uma revista comercial.

Revista Crioula: E quem formava, de início, o Grupo?

Salim Miguel: Éramos Eglê e eu, mais um professor chamado Aníbal Nunes Pires, a quem devemos muito, pois já era um nome conhecido na época, professor dos dois colégios - um feminino e outro masculino - mais importantes de Santa Catarina. Havia também o Oddy Fraga, que foi nosso diretor de teatro.

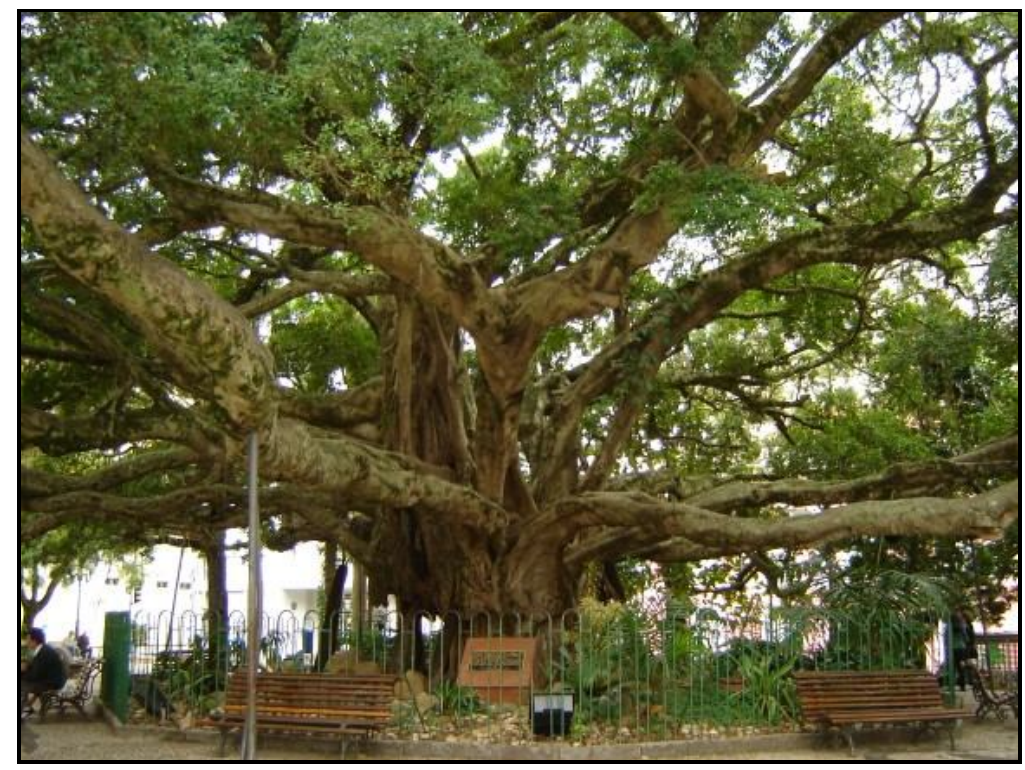

A grande figueira da Praça XV, em Florianópolis, um dos locais onde se reuniam os jovens do Grupo Sul

Eglê Malheiros: E Antonio Paladino, Claudio Bousfield Vieira, Armando Carreirão, Élio Balstaedt, Hamilton Valente Ferreira, Fúlvio Luis Vieira, Walmor Cardoso da Silva, Archibaldo Cabral Neves. 
Salim Miguel: Sim, à medida que a revista foi se firmando, surgiram outros nomes: Martinho de Haro, Aldo Nunes, Moacir Fernandes, Hassis, Hugo Mund Jr, Meyer Filho, Guido Wilmar Sassi, Adolfo Boos Jr, Silveira de Souza. A gente costuma dizer que se a Sul não teve outro resultado, pelo menos modificou o panorama cultural de Florianópolis e Santa Catarina e deixou alguns nomes na poesia, na ficção e nas artes plásticas.

Eglê Malheiros: Os jovens que formavam o Grupo Sul queriam se projetar. Havia um professor da Faculdade de Direito, o desembargador Henrique da Silva Fontes, conservador, mas com uma abertura para a juventude que era uma coisa incrível: em nossas conferências o professor Fontes estava sentadinho lá na primeira fila. Ele era grande admirador de Cruz e Souza e sempre nos convidava quando fazia alguma homenagem ao poeta. Foi meu professor na Faculdade de Direito. Uma vez, eu tinha publicado um poema e ele me chamou: "Dona Eglê, por favor, gostei do seu poema, mas em atenção a um velho professor como eu, ponha aqui as vírgulas e os pontos!”

Salim Miguel: Ele era desembargador e professor, mas gostava de ser chamado de professor. Um dia, ele nos encontrou e disse assim: "Arte moderna, arte moderna, coisa curiosa: vocês marcaram uma palestra para anteontem... vocês não foram e nem o palestrante, mas eu fui!" É que nós estávamos reunidos num bar e começamos a conversar, a discutir e a beber e o próprio conferencista se esqueceu da palestra!

Mas voltando à revista, para lançá-la, como nós não tínhamos - e nem queríamos ter, porque primávamos pela inteira independência - nenhum contato com os poderes estabelecidos, montamos um espetáculo de teatro com três peças em um ato: Pirandello, Shaw. Na primeira, uma peça com o nome "Um homem ser paisagem", do diretor do grupo, Oddy Fraga. O segundo espetáculo foi uma adaptação de um conto de Sartre. Vejam: foi a primeira vez que Sartre foi representado no Brasil. Isso em 1948, aqui em Florianópolis. Com o resultado da bilheteria do espetáculo nos dois dias em que foi apresentado, conseguimos tirar três números da revista! 
Revista Crioula: E qual era a tiragem da revista?

Salim Miguel: Mil exemplares. E hoje a nossa coleção é única, nem na Biblioteca Central da Universidade, nem na Biblioteca Pública do Estado há a coleção completa da revista.

Nós temos uma carta de 1988, do Prof. Agostinho da Silva, um português exilado, figura importantíssima para a cultura no Brasil, pois ele ajudou a criar a Universidade Federal de Santa Catarina, da Paraíba, de Brasília - o Darcy Ribeiro levou-o para ajudar a criar a Universidade de Brasília - e o Centro de Estudos Afro-Orientais na Universidade Federal da Bahia. Em 1988, ele estava em Moçambique e me mandou um bilhete dizendo assim... aliás, eu transcrevo o bilhete na contracapa de Cartas d'África e alguma poesia... veja lá o que ele diz:

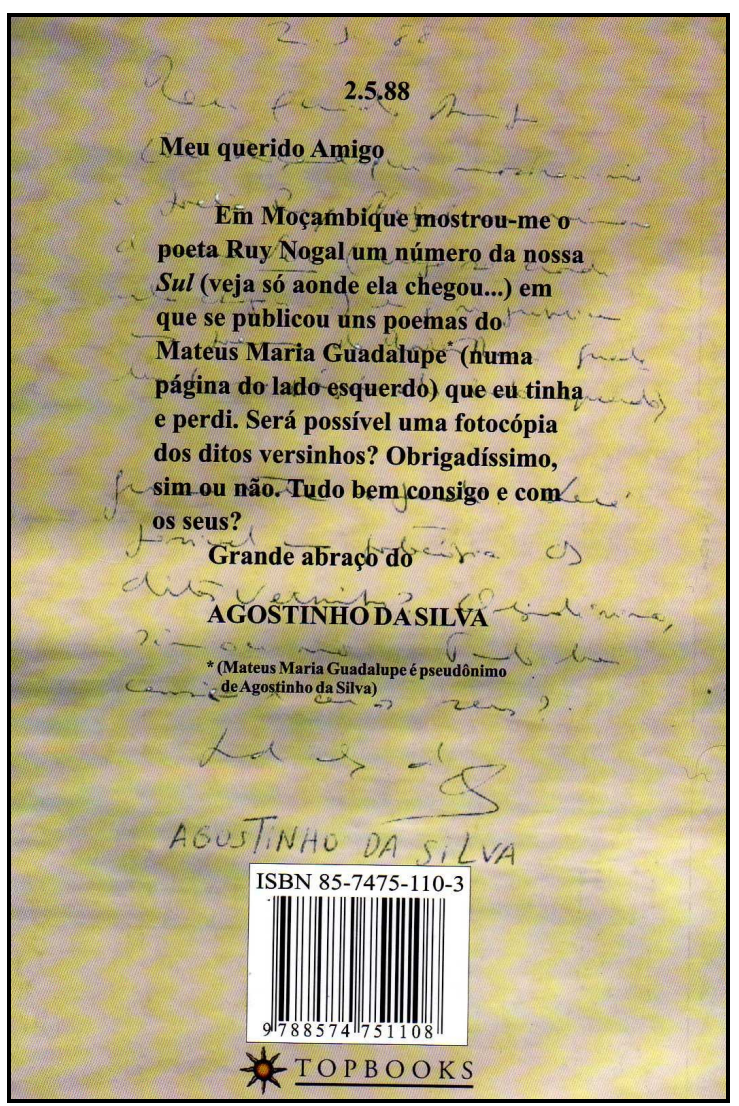

Contracapa da obra Cartas D’África e Alguma Poesia

Salim Miguel: Eglê e eu sempre fomos colecionadores compulsivos de tudo que é papel... o que eu tenho de cartas e correspondências! Dos portugueses 
dá para fazer dois volumes com os nomes mais representativos da literatura portuguesa dos anos 40 e 50.

Revista Crioula: Foi a Professora Tania Macêdo quem teve um dos primeiros contatos com Salim Miguel a respeito da Revista Sul no começo dos anos noventa?

Salim Miguel: Sim, isso talvez tenha sido resultado do I Encontro de Professores de Literaturas Africanas de Língua Portuguesa, realizado em 1991, na Universidade Federal Fluminense, em que saiu uma publicação com os textos - eu, por sinal, nunca tive acesso a essa publicação - e lá eu deixei o meu depoimento.

Estava lá, nesse encontro, Michel Laban, e ele não parou de me procurar quando soube que eu tinha um dos únicos três exemplares de $A$ cidade e a infância, de Luandino Vieira, que na época era ainda José Graça. A edição foi toda apreendida pela PIDE e queimada, mas o Luandino Vieira, foi ao correio e depositou três exemplares, um deles para mim. Então eu e Eglê somos possuidores de um dos três únicos exemplares do primeiro livro do Luandino. No último número da revista nós publicamos um conto dele, que é o único texto em prosa que aparece em Cartas d'África e alguma poesia.

Como nós chegamos até lá é uma coisa muito curiosa, pois Florianópolis era uma provinciazinha praticamente desconhecida nos anos 40/50, tanto assim que muita gente perguntava qual era a capital de Santa Catarina, se era Curitiba, se era Porto Alegre (risos!).

Salim Miguel: A popularidade de Florianópolis nesses últimos anos se deve em grande parte ao Gustavo Kuerten, o Guga. Mas nos anos 40 e 50, houve a contribuição da Revista Sul. Quando ela terminou, tínhamos correspondentes na maioria dos países, da China comunista à Espanha, da União Soviética aos Estados Unidos.

Salim Miguel, mostrando a revista: Eu costumo dizer que se aprende fazendo. Fizemos o primeiro número da revista em composição manual, hoje 
isso é peça de museu, porque nem o "tipo" mais existe.

Salim Miguel: Este formato inicial da revista é muito melhor que o que foi feito depois, só que os custos destes, por incrível que pareça, eram maiores, e como nós não tínhamos recursos, ou acabava a revista ou alterávamos o formato. Então, vendo os primeiros números, percebe-se que não entendíamos absolutamente nada do que era fazer uma revista. E é até bom, porque mostra isto que estou dizendo, que a gente aprende fazendo. A partir do quarto número é que ela adquire uma forma, uma "cara" de revista, de publicação.

Eglê Malheiros: Nós tivemos, é preciso que se diga, o apoio de muita gente já com nome e que foi muito carinhosa conosco. Publicávamos ilustrações de artistas renomados.

Revista Crioula: Eu estava vendo aqui o Gaspar Simões, o Cardoso Pires, todos escreveram na Sul...

Salim Miguel: Escrevemos sobre Fernando Namora, Alexandre O'Neill; em 1949, nós já estávamos publicando poemas de Fernando Pessoa e Miguel Torga em Florianópolis!

Revista Crioula: Como iniciou o contato com os escritores africanos?

Salim Miguel: Foi por causa do Marques Rebelo. Desde o começo fizemos contato, não só com ele, mas com Drummond, com Graciliano, com José Lins do Rego...

Revista Crioula: E com Ribeiro Couto, tiveram contato?

Salim Miguel: Não, porque Ribeiro Couto estava no exterior, na época era embaixador na Hungria. O crítico de arte e arquiteto Flávio de Aquino - que era daqui e mais adiante fez parte da equipe de Niemeyer na construção de 
Brasília - mostrou a Marques Rebelo o número 2 da Sul e, em seguida, mandou-nos uma carta comunicando o interesse de Marques Rebelo em fazer em Florianópolis, tal qual em Resende, Cataguases e Buenos Aires, uma exposição de arte contemporânea e três palestras. Imediatamente, sem medir a dificuldade que aquilo traria, respondemos afirmativamente. Obtivemos o apoio do Secretário da Educação Armando Simone Pereira e do Governador Aderbal ramos da Silva. No número 6 da revista, há três páginas com fotografias e uma reportagem sobre a exposição.

Durante o período em que o Marques Rebelo esteve aqui, soube que mantínhamos contato com autores e publicações de outros Estados - havia cerca de 40 a 50 publicações de jovens por todo o Brasil. Perguntou-nos se não gostaríamos de também entrar em contato com outros países. Nós, claro, respondemos que sim, e ele nos passou o endereço de Manuel Pinto, em Portugal, e de Augusto dos Santos Abranches, em Moçambique.

Revista Crioula: E como Marques Rebelo chegou aos autores africanos?

Salim Miguel: Eles já se correspondiam e, por acaso, se encontraram em Portugal; o Augusto dos Santos Abranches não era africano, mas português. O Marques Rebelo tinha uma coluna na Última Hora e, quando morreu o Augusto dos Santos Abranches, em São Paulo, ele fez cinco crônicas durante cinco dias, que nós republicamos em Cartas d'África e alguma poesia. Foi em Portugal que ele ficou conhecendo pessoalmente o Augusto dos Santos Abranches. Só que Augusto se refugiou em Moçambique e, depois, nem em Moçambique, devido às suas posições políticas, ele tinha espaço. Foi assim que veio tentar a sorte no Brasil e faleceu em São Paulo em 1963. Logo que Augusto recebeu nossa carta, já respondeu, enviou poemas e nos disse que havia feito contato com António Jacinto, em Angola, e que ele nos escreveria em breve. Logo em seguida recebemos uma carta de António Jacinto.

Revista Crioula: Então o primeiro escritor a manter contato com a Sul foi Augusto dos Santos Abranches, em Moçambique, e o segundo foi António Jacinto, em Angola? 
Salim Miguel: Sim. Em Moçambique, o primeiro correspondente nosso foi Augusto dos Santos Abranches e o segundo foi Manuel Filipe de Moura Coutinho.

Revista Crioula: Em Angola, o primeiro a contatarem foi António Jacinto?

Salim Miguel: Foi António Jacinto, mas aí ele já falou com Viriato da Cruz, que falou com Noémia de Sousa, e a coisa expandiu. Em 1955, recebemos a primeira carta de José Graça, bem mais jovem - tanto que, de todo aquele grupo com que nos correspondemos, o único que ainda vive é o Luandino -, dizendo que, por meio de António Jacinto e de Viriato da Cruz, ficou sabendo da Revista Sul e, como lá não tinha condições de publicar, queria saber se publicaríamos seus textos. O caso é que quando ele nos mandou mais textos, a revista já tinha acabado, porque a revista acabou em dezembro de 1957.

Revista Crioula: O primeiro número é de janeiro de 1948, não é?

Eglê Malheiros: É, a gente começou o movimento em 1947, e o primeiro número já saiu no ano seguinte.

Revista Crioula: Os escritores africanos começaram a publicar a partir de que número?

Salim Miguel: Eu não sei se foi em 1950 ou 1951.

Revista Crioula: Existe um índice geral dos autores publicados na revista?

Salim Miguel: O número 30 tem um artigo do Esdras do Nascimento com uma relação em ordem alfabética de todos os colaboradores da revista. Nós fizemos o enterro da revista com toda a pompa, com jantar, velas, falando dos méritos e dos deméritos da "falecida". O número 29 tem um artigo da 
Eglê em que diz que nós criticávamos os acadêmicos e estávamos nos transformando neles, então estava na hora de a revista acabar.

Revista Crioula: Vocês chegaram a visitar algum país africano?

Salim Miguel: Não.

Revista Crioula: O contato pessoal que tiveram com os escritores se deu naquele I Encontro de Professores de Literaturas Africanas de Língua Portuguesa realizado na UFF, em 1991, ou houve alguma ocasião anterior a isso?

Salim Miguel: Não, a Eglê nem foi a esse encontro. Na verdade, a Eglê e eu estivemos, em 1985, em Portugal. Eu tinha participado de um livro organizado pela Cremilda de Araújo Medina, chamado A posse da terra e o escritor brasileiro hoje. Ela entrevistou cerca de 50 escritores e cada escritor tinha direito a duas páginas no Estadão. Dos 50 escritores, 12 foram selecionados para ir a Portugal, e um deles fui eu. Então, nós aproveitamos a oportunidade e conhecemos muitos dos colaboradores da Sul que ainda lá viviam. Hoje, acho que ninguém mais vive... nós dois somos dois sobreviventes! Conversamos com Manuel Ferreira, que além de romances tem muitos trabalhos sobre cultura africana, tem uma antologia muito boa sobre 50 poetas africanos.

Revista Crioula: Aqui tem um cabo-verdiano: Nuno Miranda.

Salim Miguel: Com Cabo Verde nós tivemos pouco contato.

Revista Crioula: Na parte das artes, está aqui o Quirino Campo Fiorito.

Salim Miguel: Quirino foi um amigo nosso, ele e a Hilda, mulher dele.

Eglê Malheiros: O que acho interessante nessa época é a disponibilidade 
daqueles nomes já firmados de apoiar, fazer troca, incentivar, o que já não se vê mais hoje em dia.

Revista Crioula: Pois é, Carlos Drummond de Andrade, Vinicius de Moraes, Marques Rebelo, Adonias Filho, Miguel Torga...

Eglê Malheiros: Na época, nós aceitávamos aquilo como natural, publicávamos, ficávamos agradecidos, mas não tínhamos a dimensão que temos hoje do significado...

Revista Crioula: E vocês também publicavam em revistas e periódicos africanos?

Salim Miguel: É, na coleção Imbondeiro Gigante, uma espécie de antologia. O primeiro texto que saiu daqui foi o do Guido Wilmar Sassi, um escritor de Santa Catarina hoje pouco conhecido. Tenho uma carta do Garibaldino Andrade, o diretor da Imbondeiro na época, propondo a publicação de um texto meu, mas a Imbondeiro acabou antes disso acontecer. Temos a coleção completa desses cadernos e muitos livros de escritores africanos daquela época, pois eles nos mandavam.

Revista Crioula: Li numa das cartas de António Jacinto que ele os convidou para publicar no Farolim. Isso chegou a acontecer?

Salim Miguel: Eu não me lembro... meu, saiu alguma coisa, saiu artigo, por exemplo, quando faleceu o Graciliano Ramos, talvez o primeiro artigo publicado em Portugal tenha sido o meu.

Salim Miguel: Tem um texto chamado "No centenário de Marques Rebelo", que está publicado no meu livro Minhas memórias de escritores, em que falo como é que nós chegamos até os africanos por causa dele. 
Salim Miguel: A Juliana Santil esteve em Angola e contatou a filha ou a viúva de Viriato da Cruz, mas já não havia lá nenhuma das cartas que enviei a ele. Com parentes de António Jacinto ela não conseguiu maiores contatos, mas esteve com Luandino Vieira, em Portugal, e mostrou-lhe as cópias das cartas que ele me enviou... ele ficou surpreendido e falou: "Eu não sabia que eu tratava desses assuntos!” Quanto às cartas que lhe enviei, já não há mais nenhuma, uma vez que Luandino esteve preso durante 13 anos no Tarrafal e, nesse meio tempo, desapareceu todo o seu arquivo.

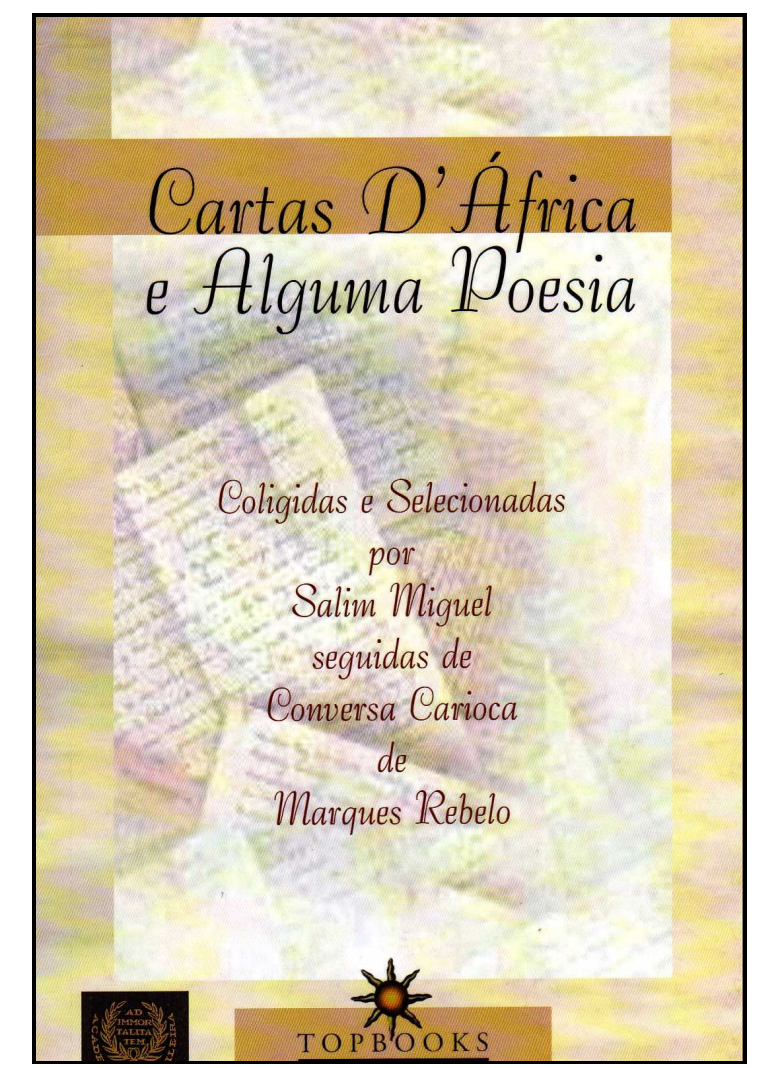

Capa da obra Cartas D’África e Alguma Poesia

Revista Crioula: Uma coisa que me chamou a atenção nas cartas é as manobras que eram feitas para driblar a apreensão pela PIDE dos livros enviados aos escritores africanos...

Salim Miguel: Durante um ano nós tivemos também uma página no principal jornal de Santa Catarina, O Estado, e lá nós publicamos alguma coisa de escritores portugueses e africanos. Se não me engano, de Cabo Verde acho que tem um... 
Revista Crioula: Chegaram a trocar correspondência com Noémia de Sousa?

Salim Miguel: Não, embora tenhamos publicado dois ou três poemas dela.

Revista Crioula: Com a Glória de Sant'Anna também não?

Salim Miguel: Não também.

Salim Miguel: Há uma carta que ainda não foi publicada, mas agora o José Gonçalves ia a Angola e pediu xerox de duas ou três cartas e um texto meu para uma publicação lá. Ele queria também uma carta inédita, que não estivesse em Cartas d'África e alguma poesia. Acabamos, Eglê e eu, encontrando uma cuja assinatura não conseguimos decifrar - os envelopes a gente não guardava. Nós deveríamos ter feito uma referência e ter publicado, porque é uma carta importante. Aí eu disse a José Gonçalves que ia selecionar duas cartas, uma do Viriato da Cruz e outra do Luandino ou do António Jacinto, e que mandaria também essa outra inédita. Ele ficou entusiasmado, porque quem assina fala em nome de um grupo de jovens que tinha tomado conhecimento da revista e que o grande sonho deles era publicar na revista Sul. Só que a carta é de 1957, quando a revista estava acabando, e deve ser publicada na revista angolana - esqueci o nome da revista agora - em novembro.

Eglê Malheiros: A Revista Sul chegou a lugares que a gente nem sonha, porque um mandou para o outro, que mandou para outro, e assim por diante. Tivemos poemas traduzidos para o espanhol, para o francês...

Salim Miguel: Quando nós voltamos desse giro por Portugal, em 1985, eu trabalhava para um jornal daqui chamado $O$ Estado e publiquei uns três ou quatro artigos em que transcrevo um trecho de um diálogo entre o Manuel Ferreira e um jovem escritor, já falecido, que era redator-chefe do Jornal de Letras de Portugal, um jornal muito importante na época. O diálogo era mais 
ou menos o seguinte: Manuel Ferreira dizia que, embora conhecesse e recebesse a Revista Sul, nunca teve um texto publicado nela, e esse jovem jornalista e poeta respondia assim: "Pois eu, com 16 anos, tive meu primeiro texto publicado na Revista Sul.” Bonito, né? Uniram-se as duas pontas: um que já era um nome de referência, que tem uns três romances sobre a África, embora seja mais conhecido enquanto crítico e estudioso da literatura, especialmente da poesia. Pois bem, logo no começo, embora tivéssemos recebido os seus romances, dito a respeito e nos correspondêssemos, jamais publicamos um texto de de Manuel Ferreira. Ele comentava: "Veja só, jamais tive um texto publicado na Sul e hoje, pra mim, isso faz falta”, ao que o outro retrucava: "Já eu, com 16 anos, antes de publicar em Portugal, publiquei na Sul”.

Revista Crioula: É, pelo que diz aqui o Nuno Miranda, a revista chegava a Cabo Verde. Ele disse que conquistou a geração dos novos de Cabo Verde, ou seja, a geração da Claridade...

Salim Miguel: Da Claridade nós recebemos um ou dois exemplares.

Revista Crioula: Pois é, então havia um intercâmbio com o grupo da Claridade... de fato, a Revista Sul tem semelhanças muito grandes, quanto ao tipo de editoração e à diversidade, com a Claridade: aborda teatro, poesia, artes plásticas. É interessante fazer a relação da Revista Sul com as revistas africanas...

Salim Miguel: Nós não tínhamos a idéia de como havíamos chegado aos mais distantes países, e países com uma visão tão distanciada do que é o processo cultural no seu sentido mais amplo: tínhamos, por exemplo, um correspondente na Tchecoeslováquia.

Revista Crioula: Com o Augusto dos Santos Abranches o contato me pareceu maior... 
Eglê Malheiros: Quando nós nos casamos, ele nos mandou um presente: uma aldeia africana esculpida... quer ver?

Revista Crioula: Que lindo!

Salim Miguel: Algumas peças se perderam nas várias mudanças que fizemos, mas ainda dá para ter uma idéia do conjunto.

Revista Crioula: São muito interessantes as cartas do Augusto: ele, no início da troca de correspondência entre vocês, era todo formal:"Prezado Senhor”... mas algum tempo depois, já troçava: "Diabo duma figa”!

\section{(Risos gerais)}

Salim Miguel: Pois é, com quem a gente teve mais contato mesmo, depois do Augusto, foi com António Jacinto, Viriato da Cruz e Luandino. Mas Viriato logo brigou em Angola, foi para Paris, brigou também em Paris e foi para a China. Na China, no começo ele estava tão bem, tinha um belo apartamento, um salário bom, mas aí ele começou a não gostar de algumas coisas que via e brigou lá também. Há um livro com uma correspondência dele para uma amiga francesa que é um documento importantíssimo sobre o problema dele e como é que ele estava vendo a China comunista. É um negócio impressionante a visão que Viriato tinha. Era um homem inteligentíssimo. Acho que, de todos que nós conhecemos, era Viriato quem tinha uma visão de mundo mais clara, só que adorava uma briga! (risos!)

Revista Crioula: Então com o António Jacinto também havia uma correspondência freqüente?

Salim Miguel: É, depois é que perdemos contato porque o António Jacinto, da mesma forma que Luandino, passou 13 anos no Tarrafal. Mas depois, no primeiro governo após a independência de Angola, António Jacinto foi Ministro da Cultura do Agostinho Neto. Uma coisa curiosa é que tínhamos 
os livros de Agostinho Neto e nunca publicamos nenhum poema dele na Sul. É dessas coisas que a gente não sabe como explicar...

Eglê Malheiros: Mas também havia muita correspondência que se perdia: mandavam colaboração e não chegava...

Salim Miguel: É, tem um bilhete da censura curiosíssimo: nós nunca tivemos sede, então dizíamos que nos reuníamos na caixa-postal 384. De repente, não sei se fui eu ou o Walmor - que foi secretário da revista - quem o apanhou, chegou um bilhete dizendo assim: "Senhores da caixa-postal 384, estamos thes devolvendo os números da Revista Sul, pois, de acordo com a legislação vigente, eles não podem entrar em território português e das colônias africanas". Eles abriam os pacotes.

Revista Crioula: Por isso é que tinha que separar de 100 em 100 páginas e retirar a capa, né?

Salim Miguel: É, o Viriato da Cruz tem uma carta em que diz isso, está em Cartas d'África e alguma poesia.

Revista Crioula: Mas, em geral, os livros chegavam ao destinatário?

Salim Miguel: Quando os livros iam desse jeito, sim. Teve um livro que nós mandamos despedaçado em três partes, sem a capa. Nós mandávamos daqui, para eles, as mais recentes edições de autores brasileiros; eles gostavam muito de Jorge Amado, mas gostavam mais do Graciliano Ramos. O Augusto dos Santos Abranches, por exemplo, conhecia mais literatura brasileira do que muitos autores brasileiros.

Revista Crioula: Erico Veríssimo?

Salim Miguel: Erico Veríssimo... e poetas como Drummond, Vinicius, Manuel Bandeira... há uma carta do Augusto em que ele fala deles todos. 
Revista Crioula: Ah, é! Ele diz: "permita-me uma vaidadezinha" e começa a citar os nomes, não é?!

Salim Miguel: Ah, é! Ele diz isso! (gargalhadas!) Então nós trocávamos toda essa gama de edições de autores brasileiros com eles, tanto que numa conversa com Graciliano, uma vez, lá no Rio, eu disse a ele: "Você é mais conhecido em Angola que aqui...” Ele: “Conhecido em Angola, como?" Eu disse: "Tenho uma carta que fala em seu nome..."

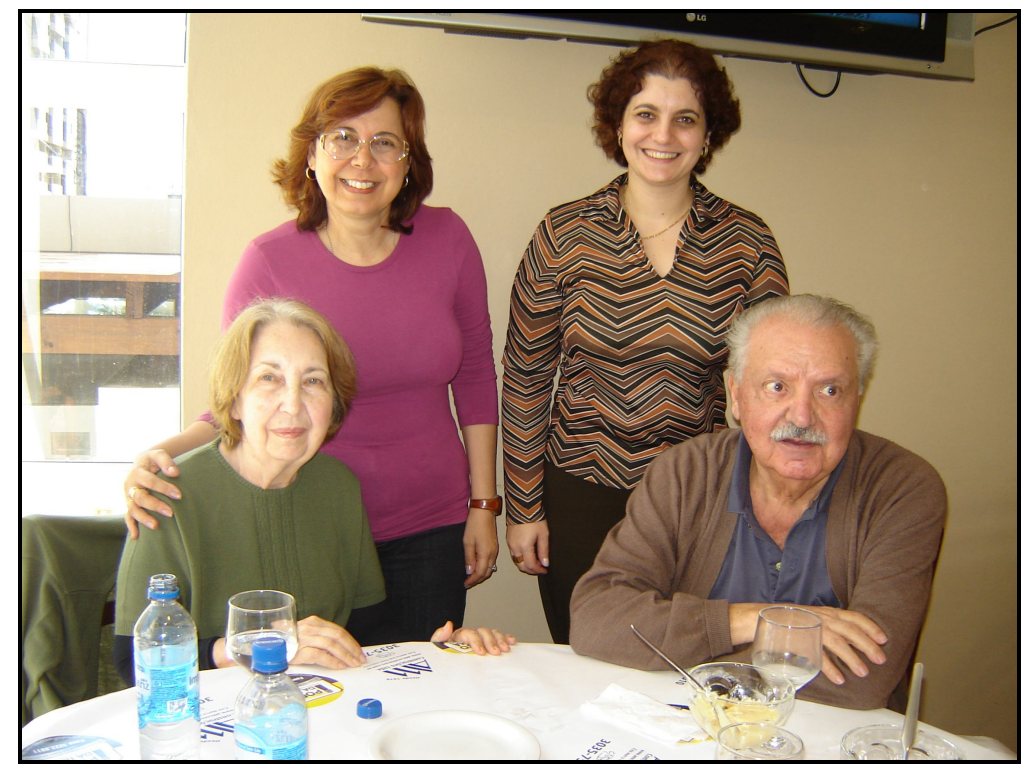

Simone Caputo Gomes, Érica Antunes e os entrevistados

Fotos: Érica Antunes

\footnotetext{
i Érica Antunes é doutoranda do Programa de Pós-Graduação em Estudos Comparados de Literaturas de Língua Portuguesa da Universidade de São Paulo (USP) e bolsista da Fundação de Amparo à Pesquisa do Estado de São Paulo (FAPESP). E-mail: erica.antunes@gmail.com.

ii Simone Caputo Gomes é Professora Doutora do Programa de Pós-Graduação em Estudos Comparados de Literaturas de Língua Portuguesa da Universidade de São Paulo (USP). Email: simonecaputog@gmail.com.
} 